\title{
Airborne measurements of new particle formation in the free troposphere above the Mediterranean Sea during the HYMEX campaign
}

\author{
C. Rose $^{1}$, K. Sellegri ${ }^{1}$, E. Freney ${ }^{1}$, R. Dupuy ${ }^{1}$, A. Colomb ${ }^{1}$, J.-M. Pichon ${ }^{1}$, M. Ribeiro ${ }^{1}$, T. Bourianne ${ }^{2}$, F. Burnet ${ }^{2}$, and \\ A. Schwarzenboeck ${ }^{1}$ \\ ${ }^{1}$ Laboratoire de Météorologie Physique CNRS UMR6016, Observatoire de Physique du Globe de Clermont-Ferrand, \\ Université Blaise Pascal, Aubière, France \\ ${ }^{2}$ Centre National de Recherches Météorologiques - Groupe d'étude de l'Atmosphère Météorologique, Meteo France/CNRS, \\ Toulouse, France
}

Correspondence to: K. Sellegri (k.sellegri@opgc.cnrs.fr)

Received: 26 January 2015 - Published in Atmos. Chem. Phys. Discuss.: 18 March 2015

Revised: 24 July 2015 - Accepted: 30 July 2015 - Published: 14 September 2015

\begin{abstract}
While atmospheric new particle formation (NPF) has been observed in various environments and was found to contribute significantly to the total aerosol particle concentration, the production of new particles over open seas is poorly documented in the literature. Nucleation events were detected and analysed over the Mediterranean Sea using two condensation particle counters and a scanning mobility particle sizer on board the ATR-42 research aircraft during flights conducted between 11 September and 4 November 2012 in the framework of the HYMEX (HYdrological cycle in Mediterranean EXperiment) project. The main purpose of the present work was to characterize the spatial extent of the NPF process, both horizontally and vertically. Our findings show that nucleation is occurring over large areas above the Mediterranean Sea in all air mass types. Maximum concentrations of particles in the size range 5-10 $\mathrm{nm}\left(N_{5-10}\right)$ do not systematically coincide with lower fetches (time spent by the air mass over the sea before sampling), and significant $N_{5-10}$ values are found for fetches between 0 and $60 \mathrm{~h}$ depending on the air mass type. These observations suggest that nucleation events could be more influenced by local precursors originating from emission processes occurring above the sea, rather than linked to synoptic history. Vertical soundings were performed, giving the opportunity to examine profiles of the $N_{5-10}$ concentration and to analyse the vertical extent of NPF. Our observations demonstrate that the process could be favoured above $1000 \mathrm{~m}$, i.e. frequently in the free
\end{abstract}

troposphere, and more especially between 2000 and $3000 \mathrm{~m}$, where the NPF frequency is close to $50 \%$. This vertical distribution of NPF might be favoured by the gradients of several atmospheric parameters, together with the mixing of two air parcels, which could also explain the occurrence of the process at preferential altitudes. In addition, increased condensation sinks collocated with high concentrations of small particles suggest the occurrence of NPF events promoted by inputs from the boundary layer, most probably associated with convective clouds and their outflow. After their formation, particles slowly grow at higher altitudes to diameters of at least $30 \mathrm{~nm}$ while not being greatly depleted or affected by coagulation. Our analysis of the particle size distributions suggests that particle growth could decrease with increasing altitude.

\section{Introduction}

New particle formation (NPF) is a widespread phenomenon in the atmosphere which results from a complex sequence of multiple processes including two major steps (Kulmala and Kerminen, 2008): (1) the formation of clusters from the gaseous phase and (2) the growth of these clusters up to sizes at which they may influence the climate through cloud related radiative processes (Kerminen et al., 2012; Makkonen et al., 2012). Observations of the phenomenon in vari- 
ous environments are reported in the literature (Kulmala et al., 2004), including boundary layer (BL) polluted locations (e.g. Brock et al., 2003; Wiedensohler et al., 2009), clean or rural sites (e.g. Suni et al., 2008), high-altitude stations (e.g. Venzac et al., 2008; Boulon et al., 2010; Rose et al., 2015a), polar areas (e.g. Asmi et al., 2010), and coastal sites (e.g. O'Dowd et al., 1998, 2002). NPF events' characteristics, such as spatial extent, both vertical and horizontal (Crumeyrolle et al., 2010; Boulon et al., 2011), particle formation and growth rates (Manninen et al., 2010; Yli-Juuti et al., 2011), are known to be affected by atmospheric parameters, including the number of gaseous precursors, the concentration of pre-existing aerosol particles, and meteorological variables (temperature, relative humidity, solar radiation). However, current knowledge of the theory that lies beyond NPF remains poor, especially at high altitudes, i.e. above $1000 \mathrm{~m}$, and a more profound understanding of the mechanisms and precursors involved in nucleation and particle growth is currently required, especially to improve the accuracy of climate modelling studies.

Marine aerosol particles, as one of the main contributors to the natural aerosol emissions, have been the focus of the attention in the scientific community for several decades (e.g. Heintzenberg et al., 2000, and references therein). In these pristine environments, changes in the aerosol burden might have significant impacts on cloud properties, as shown in recent studies (Tao et al., 2012; Koren et al., 2014; Rosenfeld et al., 2014). Marine aerosol has a primary component, known as "sea spray aerosol", which results from the interaction between wind and water surface, and a secondary component, which is in the scope of the present work. Current knowledge regarding NPF in the marine boundary layer mainly concerns coastal regions (O'Dowd et al., 1998, 2002; O'Dowd and de Leeuw, 2007), where observations of NPF are more abundant than over the open ocean. Many studies have concentrated on the comprehension of the mechanisms and the identification of the precursors involved in the NPF process from coastal macroalgae fields (O'Dowd and de Leeuw, 2007, and references therein), including both model studies (Pirjola et al., 2000) and chamber experiments (Sellegri et al., 2005). A schematic view of the marine aerosol production in coastal areas based on observations from the Mace Head station (Ireland) is given by Vaattovaara et al. (2006). In contrast, the scarcity of open-ocean nucleation studies reported in the literature might indicate that the NPF process does not occur with a high probability over the open ocean.

While ground-based stations allow indirect analysis of the horizontal extent of NPF (Kristensson et al., 2014; Rose et al., 2015b), airborne aerosol measurements can add relevant information on both the horizontal and vertical extent of NPF. Such measurements were conducted over the boreal environment, in the vicinity of the Hyytiälä SMEAR-II station, using aircraft (O'Dowd et al., 2009; Schobesberger et al., 2013) as well as motorized hang glider/microlight aircraft (Junkermann, 2001, 2005) or balloons (Boy et al., 2004; Laakso et al., 2007). These studies, based on a limited number of observations, delivered contrasting results indicating that nucleation could occur not only throughout the boundary layer but also in the free troposphere in some cases (Laakso et al., 2007), with no clear trend or preference. Airborne studies conducted in different environments are also reported in the literature, showing evidence for the occurrence of NPF in the free troposphere above Europe during the EUCAARILONGREX project (Mirme et al., 2010) and above the Arctic region, up to $7 \mathrm{~km}$, by Khosrawi et al. (2010) during the project ASTAR 2004. In contrast, using a restricted number of aircraft vertical soundings, Crumeyrolle et al. (2010) suggest that over the North Sea, NPF could be limited to the top of the boundary layer.

Giving more insights into the vertical development of the NPF process in the marine troposphere is one of the main objectives of the present study based on aircraft measurements conducted above the Mediterranean sea between 11 September and 4 November 2012 in the framework of the HYMEX (HYdrological cycle in Mediterranean EXperiment) project. We report particle size distributions and concentrations measured with a scanning mobility particle sizer (SMPS) and condensation particle counters (CPCs) deployed on board the French ATR-42 aircraft. The occurrence of NPF is investigated, with a special focus on the horizontal and vertical extents of the process, coupled with an analysis of several atmospheric parameters expected to explain these extents.

\section{Measurements and methods}

\subsection{Instruments on board ATR-42 aircraft}

As part of the HYMEX project, the ATR-42 research aircraft, operated by SAFIRE (Service des Avions Français Instrumentés pour la Recherche en Environnement), was based at Montpellier airport, in the south of France. A total of 28 flights were performed between 11 September and 4 November 2012 (Table 1).

The instrumental setup deployed on board and used for the analysis of NPF consisted of two CPCs and an SMPS. The CPCs, developed at the Max Planck Institute for Polymer Research, Mainz, Germany, are specifically dedicated to aircraft measurements (Weigel et al., 2009). Their nominal $50 \%$ lower cut-off diameter can be varied by changing the temperature difference between saturator and condenser. During HYMEX, one of the CPCs was measuring with a cutoff diameter of $5 \mathrm{~nm}$ and the second with a cut-off diameter of $10 \mathrm{~nm}$. The time resolution of the CPCs was set to $1 \mathrm{~s}$. The SMPS system is described in Crumeyrolle et al. (2010) and consists of a CPC (TSI, 3010), a differential mobility analyser (DMA) and a krypton aerosol neutralizer. The SMPS provided particle size distributions in the diameter range 20$485 \mathrm{~nm}$, with a time resolution of $130 \mathrm{~s}$. 
Table 1. Overview of ATR-42 flights performed during the HYMEX campaign between 11 September and 4 November 2012 and discussed in the present study. The range of latitudes (longitudes) corresponds to the minimum and maximum latitudes (longitudes) reached during the flight. Dominant air mass origins are reported in the last column according to the following abbreviations: WE for western Europe, SMS for southern Mediterranean Sea, EMS for eastern Mediterranean Sea and NE for northern Europe.

\begin{tabular}{|c|c|c|c|c|c|}
\hline $\begin{array}{l}\text { Date } \\
\mathrm{dd} / \mathrm{mm} / \mathrm{yyyy}\end{array}$ & $\begin{array}{l}\text { Take-off - } \\
\text { landing times } \\
\text { (UTC) }\end{array}$ & $\begin{array}{l}\text { Flight } \\
\text { number }\end{array}$ & Range of latitudes & Range of longitudes & $\begin{array}{c}\text { Dominant air } \\
\text { mass origin }\end{array}$ \\
\hline $12 / 09 / 2012$ & $10: 10-12: 51$ & 34 & $43.5456-45.0286$ & $2.8660-4.7834$ & WE \\
\hline $12 / 09 / 2012$ & 08:19-09:21 & 35 & $42.5497-43.6403$ & $3.9525-9.4847$ & WE \\
\hline $12 / 09 / 2012$ & $10: 42-14: 20$ & 36 & $42.5390-45.4146$ & $7.8651-13.4646$ & WE \\
\hline $12 / 09 / 2012$ & $15: 22-16: 49$ & 37 & $42.5700-43.5800$ & $3.9678-9.5748$ & WE \\
\hline $13 / 09 / 2012$ & $19: 55-20: 40$ & 38 & $43.4635-43.7027$ & $3.9490-4.3397$ & $\mathrm{NE}$ \\
\hline 23/09/2012 & $14: 12-17: 18$ & 39 & $42.4688-435495$ & $3.5163-6.6463$ & WE \\
\hline 26/09/2012 & 06:09-09:32 & 40 & $42.2836-43.5358$ & $4.0795-7.1505$ & WE \\
\hline 28/09/2012 & $14: 57-20: 26$ & 41 & $39.0247-43.5556$ & $1.1929-4.7809$ & SMS \\
\hline $02 / 10 / 2012$ & $19: 43-22: 11$ & 42 & $43.5345-43.7472$ & $3.9718-4.3507$ & WE \\
\hline $11 / 10 / 2012$ & $06: 18-09: 51$ & 43 & $41.5560-43.6521$ & $3.7292-6.0734$ & WE \\
\hline $12 / 10 / 2012$ & $01: 10-04: 22$ & 44 & $40.1657-43.6594$ & $3.9816-11.6052$ & WE \\
\hline $12 / 10 / 2012$ & $05: 43-07: 05$ & 45 & $42.6541-43.4451$ & $4.2909-9.5552$ & WE \\
\hline $14 / 10 / 2012$ & 08:19-11:34 & 46 & $40.0262-43.6537$ & $2.1463-7.9019$ & WE \\
\hline $14 / 10 / 2012$ & $13: 05-15: 31$ & 47 & $39.7553-43.5284$ & $4.0702-5.3839$ & SMS \\
\hline $15 / 10 / 2012$ & $05: 16-06: 33$ & 48 & $42.5505-43.6523$ & $3.9556-9.5761$ & SMS \\
\hline $15 / 10 / 2012$ & $07: 47-10: 59$ & 49 & $37.9256-42.8283$ & $9.4726-13.0133$ & SMS/WE \\
\hline $15 / 10 / 2012$ & $12: 25-13: 49$ & 50 & $42.6096-43.5476$ & $4.0322-9.5697$ & NE/WE \\
\hline $18 / 10 / 2012$ & $15: 35-19: 11$ & 51 & $41.8076-43.5819$ & $3.9640-6.6005$ & SMS \\
\hline $20 / 10 / 2012$ & $09: 54-12: 56$ & 52 & $38.1726-43.5235$ & $1.3788-4.6854$ & SMS \\
\hline 20/10/2012 & $14: 14-15: 19$ & 53 & $39.7616-43.6066$ & $3.9778-4.6306$ & SMS \\
\hline $25 / 10 / 2012$ & $19: 12-22: 18$ & 54 & $38.7128-43.5761$ & $1.2494-4.6609$ & SMS/WE \\
\hline $26 / 10 / 2012$ & $23: 25-01: 24$ & 55 & $39.8828-43.6801$ & $0.2893-4.1770$ & WE \\
\hline $27 / 10 / 2012$ & $05: 52-09: 18$ & 56 & $41.2303-43.6439$ & $3.9513-7.2013$ & WE \\
\hline 29/10/2012 & $14: 06-16: 33$ & 57 & $43.4495-43.7011$ & $3.9438-4.3705$ & $\mathrm{NE}$ \\
\hline $30 / 10 / 2012$ & $21: 41-01: 16$ & 58 & $41.2096-43.6470$ & $3.9474-7.0443$ & Local \\
\hline $31 / 10 / 2012$ & $02: 24-05: 29$ & 59 & $40.8767-43.2733$ & $4.9027-10.4004$ & SMS \\
\hline $03 / 11 / 2012$ & $08: 01-11: 35$ & 60 & $41.9706-43.6533$ & $3.9881-8.0024$ & WE \\
\hline $04 / 11 / 2012$ & $10: 06-12: 29$ & 61 & $41.9660-43.6798$ & $3.8330-8.1176$ & WE \\
\hline
\end{tabular}

The ATR-42 was also equipped with additional instruments dedicated to the analysis of aerosol and cloud properties: a particle soot Absorption photometer allowing the monitoring of black carbon concentration (PSAP; Bond et al., 1999), an optical particle counter (OPC, GRIMM), a compact aerosol time-of-flight mass spectrometer (AMS; Drewnick et al., 2005) and a fast forward-scattering spectrometer probe (Fast-FSSP). The aerosol instrumentation was connected to the community aerosol inlet (CAI), which has a $50 \%$ sampling efficiency for particles larger than $5 \mu \mathrm{m}$ (see Crumeyrolle et al., 2010, and references therein for more details). Routine meteorological variables were continuously monitored.

\subsection{Data analysis}

\subsubsection{Sea/land mask}

The main objective of this study was to investigate the occurrence of NPF in the marine troposphere. For that purpose, all measurements conducted above land were removed from the database. An arbitrary threshold distance of $1 \mathrm{~km}$ to the coast was set to consider measurement as "marine". The distance, $D$, between two geographical points, $A$ and $B$, knowing their coordinates, was calculated according to

$$
\begin{aligned}
D & =\arccos \left(\sin \left(\phi_{A}\right) \times \sin \left(\phi_{B}\right)+\cos \left(\phi_{A}\right) \times \cos \left(\phi_{B}\right)\right. \\
& \left.\times \cos \left(\lambda_{A}-\lambda_{B}\right)\right) \times R_{\mathrm{T}},
\end{aligned}
$$

where $\phi_{Y}$ and $\lambda_{Y}$ are the latitude and longitude of the location $Y$, respectively, and $R_{\mathrm{T}}=6371 \mathrm{~km}$ is the mean radius of the Earth. The position of the points located at the threshold distance of $1000 \pm 50 \mathrm{~m}$ from the aircraft position was calculated using Eq. (1) every $10 \mathrm{~s}$ along the flight path (which 

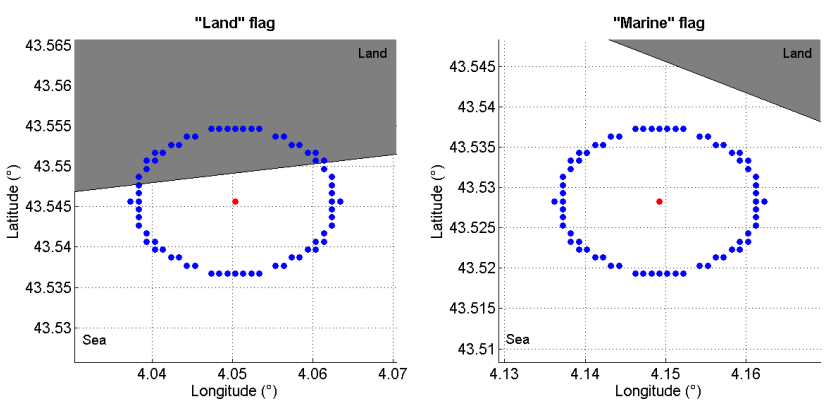

Figure 1. Method for the determination of the "marine"/"land" flag. The red point corresponds to the location of the aircraft. The blue points represent the $1000 \pm 50 \mathrm{~m}$ minimum distance from land required for a measurement to be considered as "marine".

correspond to a distance of $1 \mathrm{~km}$ for a typical aircraft speed of $100 \mathrm{~m} \mathrm{~s}^{-1}$ ) and plotted on a map. Measurements were considered as "marine" when none of these points (forming an ellipse) intercepted any coastline, as illustrated in Fig. 1. We finally assumed that the flag ("marine" or "land") obtained at a time $t$ was the same for the $5 \mathrm{~s}$ that preceded $t$ and the $4 \mathrm{~s}$ that followed $t$.

\subsubsection{Detection of nucleation events}

In order to track the occurrence of nucleation above the Mediterranean Sea and to evaluate the strength of the events, particle concentration in the size range 5-10 nm $\left(N_{5-10}\right)$ was calculated by subtracting the data readings of the two CPCs. After analysing the variability of $N_{5-10}$ apart from nucleation periods, we found that $N_{5-10}$ concentrations had an average value of $29.9 \mathrm{~cm}^{-3}$ and a standard deviation of $144.8 \mathrm{~cm}^{-3}$. Hence, $N_{5-10}$ concentrations were considered significant above the threshold value of $175 \mathrm{~cm}^{-3}$. It is worth noting that in-cloud measurements were filtered out in order to prevent the detection of elevated particle concentrations that could be sampling artefacts linked to the fragmentation of cloud droplets impacting the aerosol inlet (Weber et al., 1998).

\subsubsection{Air mass back trajectories}

The influence of air mass history on the occurrence of nucleation was studied using three days air mass back trajectories computed with the HYSPLIT transport and dispersion model (Draxler and Rolph, 2003). Three days before sampling were chosen based on previous work by Tunved et al. (2005), who estimated the turnover time of aerosol particles to be around 1.6-1.7 days for nuclei size ranges and 2.4 days for $200 \mathrm{~nm}$ particles. Back trajectories were calculated every $5 \mathrm{~min}$ along the flight path (i.e. $30 \mathrm{~km}$ for a typical aircraft speed of $100 \mathrm{~m} \mathrm{~s}^{-1}$ ) and air masses were further classified into northern Europe, western Europe, southern Mediterranean Sea, eastern Mediterranean Sea, and local types according to the maximum time spent in each sector.

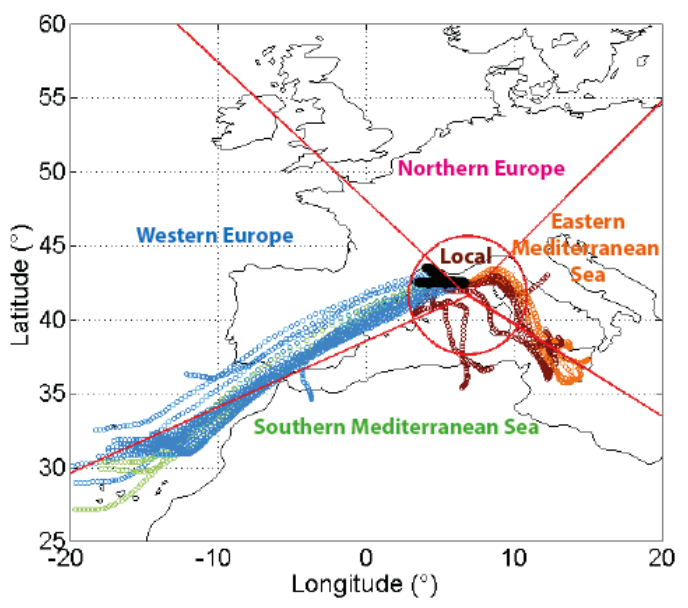

Figure 2. Illustration of the air mass back trajectories calculation along the flight path (black points) for flight 39 (23 September 2012). The colour coding of the trajectories corresponds to the sectors as given by the text colours.

As illustrated in Fig. 2, the local sector corresponds to the geographical area were most of the flights took place during the HYMEX campaign (centred on the position $41.6701^{\circ} \mathrm{N}$, $6.8769^{\circ} \mathrm{E}$ ), while northern Europe, western Europe, southern Mediterranean Sea and eastern Mediterranean Sea types are related to the sectors $45-135,135-225,225-315$ and 315 $45^{\circ}$, respectively. We made the assumption that the air mass origin obtained at a time $t$ was the same for the $150 \mathrm{~s}$ that preceded $t$ and the $149 \mathrm{~s}$ that followed $t$.

\section{Results and discussion}

\subsection{Observation of nucleation events above the Mediterranean Sea}

\subsubsection{Horizontal extent}

When considering all measurements recorded in clear-sky conditions above the sea, $26 \%$ of $N_{5-10}$ concentrations were found to exceed the threshold value. These concentrations are obtained at all times, with slightly increased probabilities in the afternoon (11:00-17:00 UTC, 29\%) compared to other time periods ( $23 \%$ for $05: 00-11: 00$ UTC and $24 \%$ for 17:00-05:00 UTC). The fact that night-time could be associated with similar probabilities for the detection of significant $N_{5-10}$ values compared to morning hours was quite unexpected since nucleation events are more frequently reported to be initiated in the morning (e.g. Dal Maso et al., 2005; Rose et al., 2015b). In fact, night-time events have already been observed, but appear to be more scarce (Lee et al., 2008; Suni et al., 2008). The origin of nanoparticles observed at night in the present study is further discussed in Sect. 3.2.2.

The location where the significant $N_{5-10}$ concentrations $\left(>175 \mathrm{~cm}^{-3}\right)$ were detected is shown in Fig. 3. The map we 


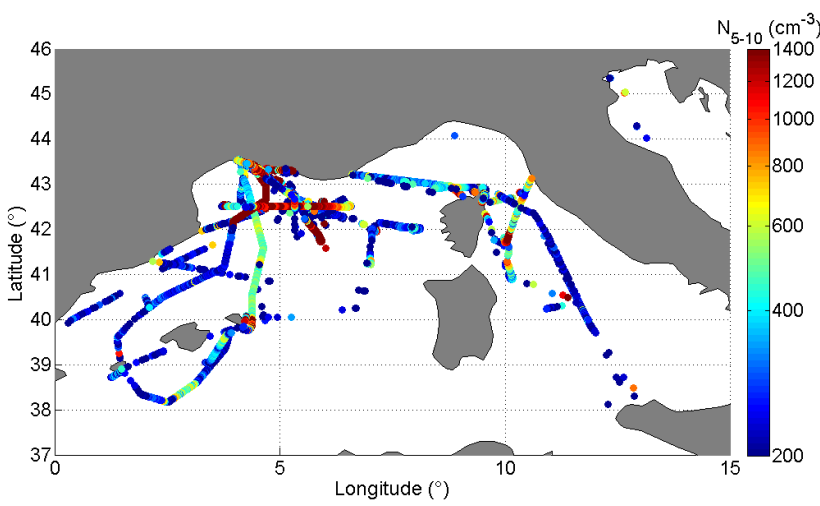

Figure 3. Location of $N_{5-10}$ concentrations exceeding the threshold value of $175 \mathrm{~cm}^{-3}$. Lower and upper limits of the colour scale were set to the 10 th and 90 th percentile of $N_{5-10}$ concentration, respectively.

obtain clearly indicates that nanoparticle concentrations are detected above the sea over large areas, being continuously detected along the flight paths over distances that can reach $\sim 580 \mathrm{~km}$ (flight 52 ). $N_{5-10}$ concentrations are in the range 235 ( 25 th percentile) -563 ( 75 th percentile) $\mathrm{cm}^{-3}$, with a median value of $328 \mathrm{~cm}^{-3}$. This range is of the order of magnitude of concentrations measured by the SMPS for larger particles (Table A1) above $2000 \mathrm{~m}$, which indicates that nucleated particles may contribute significantly to the total aerosol burden after they have grown.

According to the geographical distribution of the nucleation points in Fig. 3, it is likely that nucleation could occur at variable distances to the coast. Small particles observed close to the littoral may be expected to be produced during events initiated above land or involving gaseous precursors originating from the continental boundary layer (BL). In contrast, significant $N_{5-10}$ concentrations measured hundreds of kilometres from the shore suggest the occurrence of events which are more disconnected from continental sources, and could be rather associated with marine precursors. This point is further discussed in the following section.

\subsubsection{Influence of air mass origin - fetch of air masses}

As reported in Table 1, most of the studied flights were performed under western Europe and southern Mediterranean Sea atmospheric flows (15 and 7 out of 28 , respectively), while northern and local types were only observed during three flights. The three remaining flights were performed under variable conditions, however often dominated by western Europe and southern Mediterranean Sea flows.

Significant concentrations of small particles in the size range $5-10 \mathrm{~nm}$ were detected in all types of air masses (Table 2), but the highest nucleation probability was found in northern air masses, where $60 \%$ of $N_{5-10}$ values exceeded the threshold value. In contrast, eastern Mediterranean Sea flows showed the lowest nucleation probability, of around
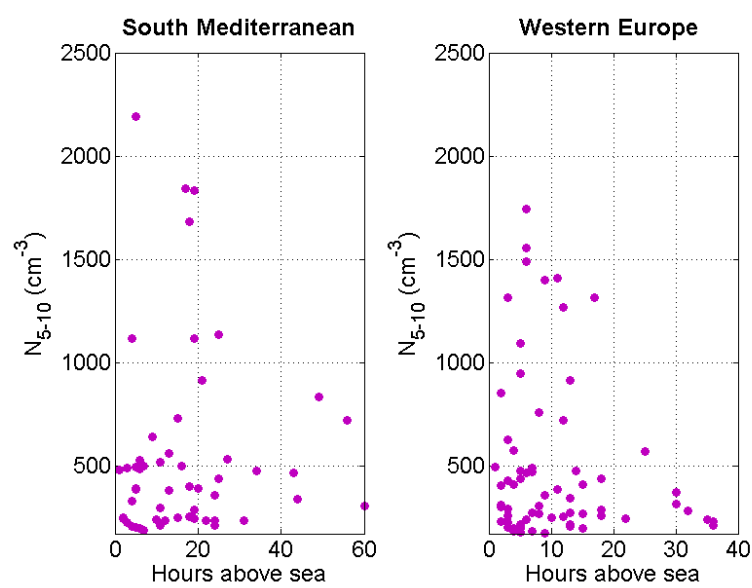

Figure 4. $N_{5-10}$ concentrations as a function of air mass fetch, separately for southern Mediterranean Sea and western Europe air masses.

$0.4 \%$. However, the values obtained for eastern, northern and local air masses may not be relevant as we have very limited statistics on them. For this reason, eastern, northern and local flows will not be further discussed. In western Europe and southern Mediterranean Sea air masses, the $N_{5-10}$ threshold value was exceeded in 23 and $32 \%$ of the cases studied, respectively. It is worth noting that the frequency of occurrence of significant ultrafine particle concentrations is relatively important in southern air masses, i.e. in air masses that have spent a significant time over the Mediterranean Sea, free of the influence of recent continental emissions.

Median $N_{5-10}$ concentrations calculated for western and southern flows were on average very similar, 315 and $361 \mathrm{~cm}^{-3}$, respectively. Based on the interquartile range (IQR), the variability of $N_{5-10}$ concentrations was relatively low for these two air mass types $\left(\mathrm{IQR}=336\right.$ and $323 \mathrm{~cm}^{-3}$, respectively). These results suggest that the strength of the events and the number of nucleated particles are not deeply impacted by air mass origin, and could instead be influenced by local (marine) atmospheric conditions.

In order to further investigate this aspect, a more detailed analysis of the number of nucleated particles as a function of the fetch, i.e. the time spent by air masses above the sea before sampling, was conducted and is reported in Fig. 4, separately for western Europe and southern Mediterranean Sea flows. Reported $N_{5-10}$ values are averaged concentrations calculated from the $60 \mathrm{~s}$ periods spanning around the times used for air mass back trajectories computation.

In western Europe and southern Mediterranean Sea air masses, fetches up to $60 \mathrm{~h}$ were calculated. In these air masses, larger concentrations are typically recorded for smaller fetches, with maximum $N_{5-10}$ values obtained for fetches around $5 \mathrm{~h}$. This last observation could either indicate that events are influenced by precursors from marine origin and have a growth rate higher than $0.8 \mathrm{~nm} \mathrm{~h}^{-1}$ or that 
Table 2. Nucleation probability and $N_{5-10}$ concentration (statistics only include $N_{5-10}$ above the threshold value) as a function of air mass origin.

\begin{tabular}{lrrrr}
\hline \multirow{2}{*}{ Air mass origin } & Nucleation probability (\%) & \multicolumn{3}{c}{$N_{5-10}\left(\mathrm{~cm}^{-3}\right)$} \\
\cline { 3 - 5 } & & Median & 25th percentile & 75th percentile \\
\hline Northern Europe & 60 & 343 & 270 & 1317 \\
Western Europe & 23 & 315 & 234 & 570 \\
Southern Med. Sea & 32 & 361 & 236 & 559 \\
Eastern Med. Sea & 0.4 & 531 & 286 & 636 \\
Local & 10 & 294 & 238 & 326 \\
\hline
\end{tabular}

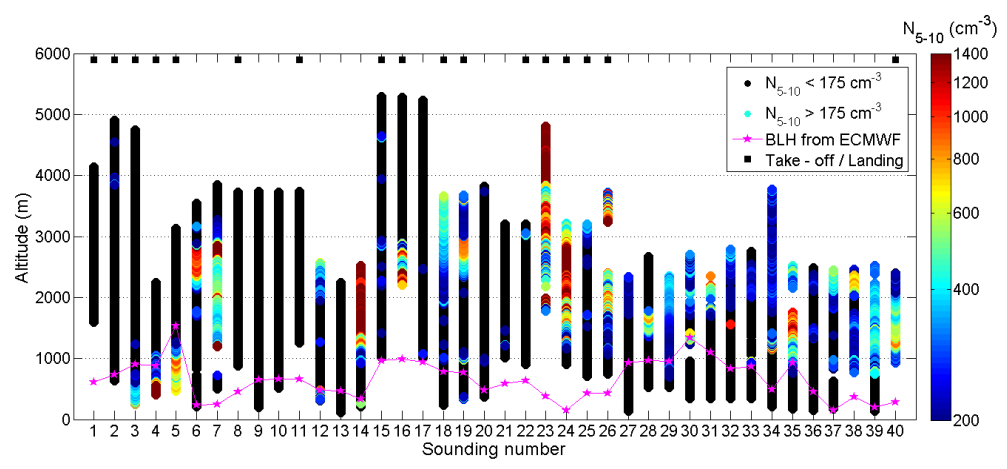

Figure 5. Profile of the $N_{5-10}$ concentrations during the ATR-42 soundings performed in clear-sky conditions above the sea. Lower and upper limits of the colour scale were set to the 1 st and 90th percentile of $N_{5-10}$ concentration, respectively. The line with pink stars corresponds to the ECMWF boundary layer height. Black rectangles highlight soundings performed during take-off or landing phase.

the detected clusters were produced over the continent and need 4 to $5 \mathrm{~h}$ before being detected by our CPC pair. However, we do detect significant concentrations of particles in the 5-10 nm size range in air masses with fetches up to $60 \mathrm{~h}$, which clearly suggests a significant marine contribution for these events and would indicate that the Mediterranean troposphere houses precursors of nucleation.

The purpose of the next section is now to investigate the vertical extent of nucleation.

\subsubsection{Vertical extent}

A total of 39 vertical soundings were performed during the studied flights, giving the opportunity to examine profiles of the $N_{5-10}$ particle concentrations. Such profiles are shown in Fig. 5. Boundary layer height (BLH) is also provided as additional information for each sounding. BLH was obtained using interpolation in space and time from the diagnosed BLH retrieved by the European Centre for Medium-Range Weather Forecasts (ECMWF) at forecast times of 3, 6, 9, $12,15,18,21$ and $24 \mathrm{~h}$, starting at 00:00 UTC, and horizontal resolution $0.25^{\circ}$. Estimations of the BLH were also obtained from the analysis of the vertical gradients of temperature, potential temperature, relative humidity and specific humidity, as suggested by Seidel et al. (2010). Reasonable agreement was found between the "gradient method" and ECMWF BLHs.

For most of the soundings, the BLH was lower than $1000 \mathrm{~m}$, being on average $662 \pm 325 \mathrm{~m}$. Fifteen profiles shown in Fig. 5 are not sufficient to allow for a complete vertical investigation of both boundary layer (BL) and freetroposphere (FT) altitudes and were thus left out (profile nos. $1,7,10,11,14,15,16,20,21,22,23,24,25,37$ and 39). For 17 of the 24 remaining profiles, $N_{5-10}$ concentrations exceeding the threshold value are mainly found above the BL, indicating that nucleation could most probably occur in the FT (profile nos. 2, 6, 13, 17, 18, 19, 26, 27, 29, 30, 31, 32, 33, $34,35,36$ and 38). Only three profiles (nos. 3, 4, 5), obtained during take-off/landing phases, show the opposite, with significant $N_{5-10}$ constrained to BL altitudes. Small particles are observed both in the BL and in the FT with no preferential altitudes identified during one sounding (28), and three profiles do not show any indication of nucleation (nos. 8, 9 and 12).

The vertical limits of the nucleation process are clearly visible for profile nos. 6 and 27. For profile no. 6, nucleation is observed between 1680 and $3170 \mathrm{~m}$, with concentrations significantly increased between 2400 and $2900 \mathrm{~m}$. During sounding no. 27 , nucleation is detected on a slightly more restricted altitude range, $1350-1780 \mathrm{~m}$, with higher concentrations between 1660 and $1710 \mathrm{~m}$. Other profiles, such as 

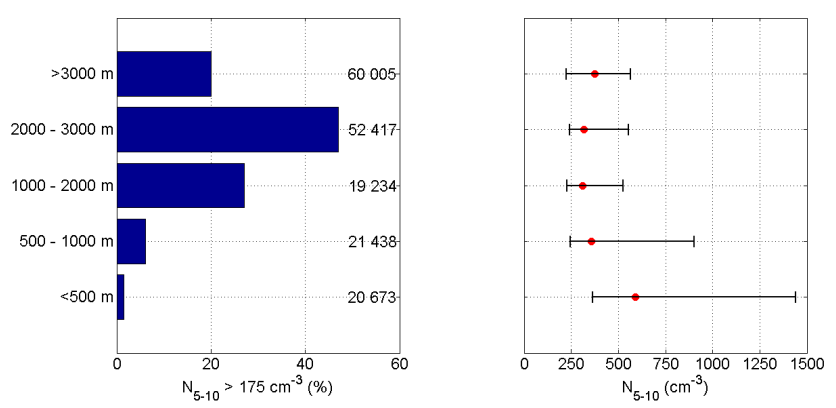

Figure 6. Statistics on the detection of significant particle concentration in the size range $5-10 \mathrm{~nm}$ as a function of altitude (left panel; the number of data points is indicated on the plot for each altitude range). Corresponding median concentrations are reported on the right panel; left and right limits of the error bars stand for the 1st and 3rd quartile, respectively.

nos. 18, 23 and 34, also display $N_{5-10}$ values which are significantly increased on a well-defined atmospheric layer above $1000 \mathrm{~m}$, not only indicating that nucleation could be promoted at higher altitudes but also suggesting the existence of preferential altitudes.

In order to further investigate the vertical extension of nucleation, all measurements were considered, i.e. $N_{5-10}$ concentrations measured during vertical soundings and also at constant altitude levels. Figure 6 (left panel) shows the percentage of $N_{5-10}$ concentrations exceeding the threshold value as a function of altitude range. As shown in Fig. 5, nucleation seems to be favoured above $1000 \mathrm{~m}$. In fact, below $1000 \mathrm{~m}$, less than $4 \%$ of the recorded concentrations were found to be significant. In contrast, nucleation probability is increased by 10 above $1000 \mathrm{~m}$, and it is worth noting that almost $50 \%$ of the concentrations obtained between 2000 and $3000 \mathrm{~m}$ exceed the threshold value, indicating that these altitudes could more especially favour the occurrence of nucleation.

However, it seems that, when nucleation events are detected, the number of nucleated particles does not significantly vary with altitude, especially above $500 \mathrm{~m}$, where median concentrations are in the range of $307-376 \mathrm{~cm}^{-3}$ (Fig. 6, right panel). Below $500 \mathrm{~m}, N_{5-10}$ concentrations are slightly increased and show higher variability, which might be caused by more inhomogeneous conditions found in this part of the atmosphere compared to higher altitudes.

The fact that nucleation could be favoured in the FT compared to the BL contradicts the results by Crumeyrolle et al. (2010), who found that NPF events were limited to the top of the BL in the North Sea. However, it is worth noting that the number of vertical profiles included in the Crumeyrolle et al. study was limited (13 profiles), and most of them were performed close to the coast.

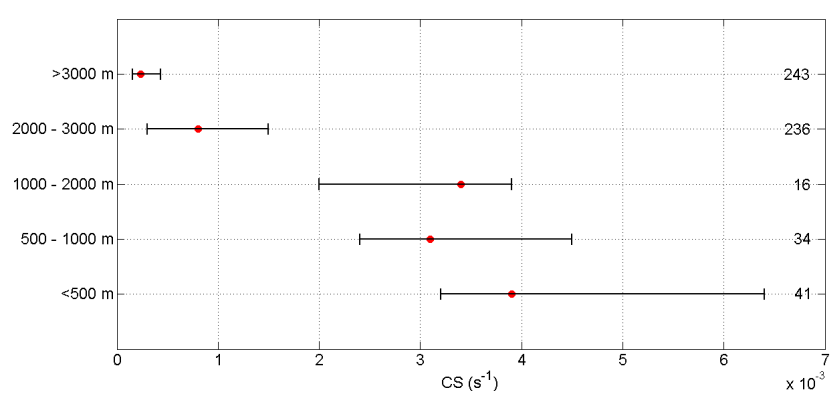

Figure 7. Median temperature and relative humidity $(\mathrm{RH})$ as a function of altitude range; left and right limits of the error bars stand for the 1 st and 3 rd quartile, respectively.

\subsubsection{Why such a vertical extension?}

The purpose of this section is to further investigate atmospheric parameters and/or processes which are associated with the higher probability of observation of small particles at higher altitudes.

Meteorological parameters, such as temperature and relative humidity $(\mathrm{RH})$, as well as global radiation, were previously reported to influence the nucleation process. Global radiation, which is expected to be more intense at higher altitudes and thus favour photochemical processes, including the oxidation of gaseous precursors involved in the nucleation process, could provide a first explanation for the observed $N_{5-10}$ vertical distribution. While low temperatures were also found to favour nucleation (Young et al., 2007), the role of RH seems to be more ambiguous. In fact, nucleation is likely to occur preferentially at low RH (Birmili et al., 2003), and both the nucleation rate and nucleated cluster concentration are reported to be anti-correlated with $\mathrm{RH}$ (Jeong et al., 2004; Sihto et al., 2006). However, nucleation events have been detected in the vicinity of clouds, where high RH is found (Clarke et al., 1998). Another aspect to consider is that, among high-altitude air masses, increased $\mathrm{RH}$ would also be associated with intrusions from the BL and hence more gaseous precursors and higher CS. The possibility for the small particles that were detected at high altitude to originate from NPF events associated with convective clouds and their outflow will be further investigated in the following.

Statistics concerning temperature and $\mathrm{RH}$ recorded during the studied flights are presented as a function of altitude range in Fig. 7. It is very clear that temperature is decreasing with altitude, especially above $3000 \mathrm{~m}$, where most of the temperatures are found to be below zero. The same trend is observed for RH, but with higher variability. $N_{5-10}$ concentrations were also directly considered as a function of temperature, $\mathrm{RH}$ and humidity mixing ratio $\left(\mathrm{g} \mathrm{kg}^{-1}\right)$, but the correlations between these meteorological parameters and the particle concentration were weak at all altitudes $\left(\left|R^{2}\right|<0.2\right)$.

Figure 8 shows, for the different altitude ranges previously introduced, the median condensation sink (CS) calculated 

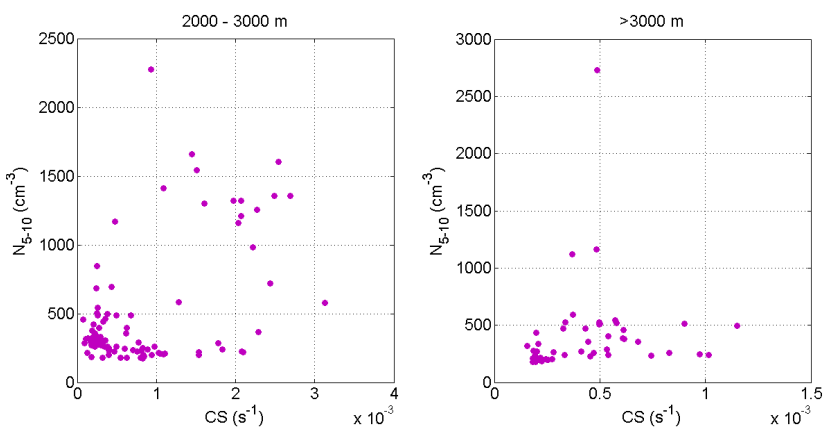

Figure 8. Median CS as a function of altitude range; left and right limits of the error bars stand for the 1st and 3rd quartile, respectively. The number of data points included in the statistics is indicated on the plot for each altitude range.

from SMPS size distributions recorded at constant altitudes, i.e. apart from vertical soundings. Up to $2000 \mathrm{~m}$, the median CS does not significantly vary with altitude, being in the range $3.1-3.9 \times 10^{-3} \mathrm{~s}^{-1}$. A higher variability observed below $500 \mathrm{~m}$ could again be explained by more inhomogeneous conditions found at low altitudes. Above $2000 \mathrm{~m}$, CS values are significantly decreased, with median values below $10^{-3} \mathrm{~s}^{-1}$. These first observations suggest that higher nucleation frequencies found above $2000 \mathrm{~m}$ could be, at least partly, explained by lower CS. The fact that nucleation could be promoted at higher altitudes due to lower CS values was also reported by Boulon et al. (2011) at the Puy de Dôme (PUY) station (1465 m a.s.l, France), where NPF is observed twice as frequently as at the BL station of Opme (660 m a.s.l.) located $12 \mathrm{~km}$ southeast of the PUY station.

A more complete analysis focussed on altitudes above $2000 \mathrm{~m}$ was then conducted to highlight the role of the CS in the nucleation process at higher altitudes. Figure 9 shows the correlation between $N_{5-10}$ particle concentration and CS, separately for the two altitude ranges above $2000 \mathrm{~m}$. The $N_{5-10}$ concentrations shown are $130 \mathrm{~s}$ averaged values coinciding with SMPS measurements used for the CS calculation. Based on Fig. 8, we observe that ultrafine particle concentration and CS are positively correlated within each altitude range, especially between 2000 and $3000 \mathrm{~m}\left(R^{2}=0.48\right)$. The lack of measurements at low altitudes did not allow for similar analyses that would make a comparison with high altitudes possible. However, higher nucleation frequencies corresponding to higher CS have already been reported in the literature for high-altitude sites (Boulon et al., 2010; Rose et al., 2015a). While lower CS values are typically reported on event days compared to non-event days at BL sites, increased CS are found on event days at high-altitude stations (Manninen et al., 2010).

In the present study, we may hypothesize that some gaseous compounds are transported, together with the preexisting particles, from lower altitudes, and that they may be further oxidized to more condensable species involved in the

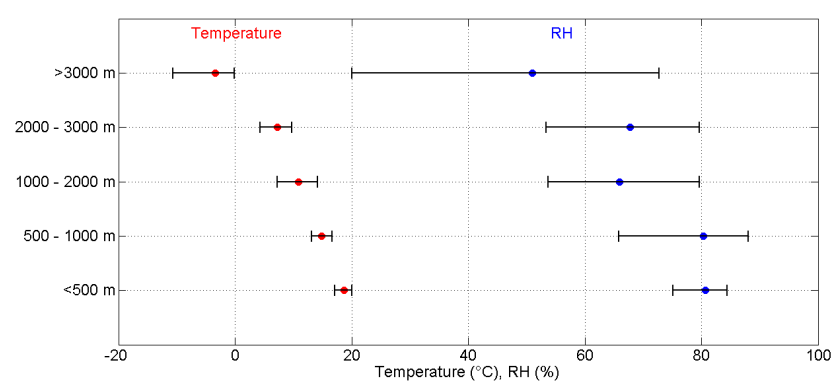

Figure 9. Particle concentration in the size range $5-10 \mathrm{~nm}$ as a function of condensation sink (CS) for altitude ranges above $2000 \mathrm{~m}$.

nucleation process. As previously mentioned, such processes might be favoured by convection associated with clouds and their outflow. In that case, the lifted air parcels where small particles are detected are expected to have different chemical signature from free-troposphere air, as well as different water vapour content. Also, the fact that clusters might be formed at lower altitudes and then be transported together with larger particles above $2000 \mathrm{~m}$ cannot be excluded. In addition, it has been previously reported by several studies that the mixing of two air parcels showing contrasting levels of $\mathrm{RH}$, temperature, condensation sink and precursors could favour the occurrence of nucleation (Nilsson and Kulmala, 1998; Khosrawi and Konopka, 2003; Dall'Osto et al., 2013).

We further investigated the contribution of cloud processes and $\mathrm{BL}$ intrusions regarding the formation of new particles using tracers such as the black carbon (BC) concentration and the specific humidity, in addition to cloud cover. Unfortunately, there was no measurement available regarding the composition of the gas phase. Our analysis was focussed on the vertical soundings performed by the ATR-42 that allow for a direct comparison of the vertical distribution of the parameters of interest (Figs. 5 and B1).

Among the 17 profiles previously associated with NPF in the FT (profile nos. 2, 6, 13, 17, 18, 19, 26, 27, 29, 30, 31, $32,33,34,35,36$ and 38 ), although cloudy conditions were filtered from our analysis, we retrieved that clouds were observed in the same altitude range as small particles in four cases (profile nos. 29, 30, 34 and 38). For three of them, collocated increases in the specific humidity (profile nos. 29 and 30) and/or BC concentration (profile nos. 30 and 34) were also found. These observations suggest that for those four particular cases, the formation of small particles was most probably induced in recently lifted air from convective clouds. For the remaining soundings, clouds were detected at lower altitudes: for sounding nos. 2, 6, 13, 18, 19, 31, 33, 35 and 36 , the vertical cloud profile was sparse, while it was denser for profile nos. 17, 26, 27 and 32. Missing data did not allow for a complete analysis of sounding nos. 18 and 36 , which will thus not be further discussed. During sounding no. 31 , high $N_{5-10}$ concentrations were found in the close vicinity of the cloud. The origin of small particles observed 
during profile nos. $6,13,27$ and 32 could not be stated unambiguously, since they were observed at altitudes characterized by low BC concentrations but median specific humidity. In contrast, the vertical distributions associated with profile nos. 2, 17, 26, 33 and 35 clearly suggest the occurrence of NPF events in free-tropospheric conditions, free of the influence of recent BL inputs. In addition, during sounding no. 19, small particles were detected around $1000 \mathrm{~m}$ and slightly below $4000 \mathrm{~m}$, while increased specific humidity and BC concentrations were observed between 2000 and $2500 \mathrm{~m}$.

We have shown so far that, above the Mediterranean Sea, NPF was observed over large areas and could be favoured at higher altitudes, since particles in the size range $5-10 \mathrm{~nm}$ are mostly seen above $1000 \mathrm{~m}$. However, the previous analysis did not always unambiguously answer the question regarding the conditions associated with the initial cluster $(1-2 \mathrm{~nm}$ particles) formation, especially in terms of the degree of $\mathrm{BL}$ influence/intrusions. Nonetheless, these particles, regardless of whether transported to or formed in the FT, in more or less polluted conditions, are expected to grow to larger diameters and might reach climate-relevant sizes in the FT. The purpose of the next section is to investigate this growth process above $2000 \mathrm{~m}$ by analysing the shape of the SMPS size distributions.

\subsection{Investigation of particle growth above $2000 \mathrm{~m}$}

\subsubsection{Analysis of SMPS particle size distributions}

SMPS size distributions $(20.4-484.5 \mathrm{~nm})$ recorded at constant altitude were fitted with four Gaussian modes, with the initial guess on the modal diameters being 25, 50, 110 and $220 \mathrm{~nm}$ for the nucleation, Aitken, first and second accumulation modes, respectively. These four modes were chosen because they most frequently came out of the fitting procedure when run without initial guesses. These diameters were previously found in the literature to describe particle size distributions in the marine atmosphere (Heintzenberg et al., 2000). The geometric mean diameters of these modes found by the fitting procedure vary from the initial guesses with time and altitude. In the following sections, the parameters of the modes (geometric mean diameter and concentration) will be used to describe the evolution of the particle size distribution.

Figure 10 shows the average fitted distributions as a function of altitude and daytime. The analysis is focussed on the highest altitude ranges, where nucleation was more frequently observed (the altitude range $1000-2000 \mathrm{~m}$ is not considered because of too few data points). The parameters of the Gaussians used for these fits are given as additional information in Table A1. The "closed" shape of the reconstructed size distributions shown in Fig. 10 is the result of the originally "open-type" size distributions that were fitted with a nucleation mode that extended below the SMPS lower size
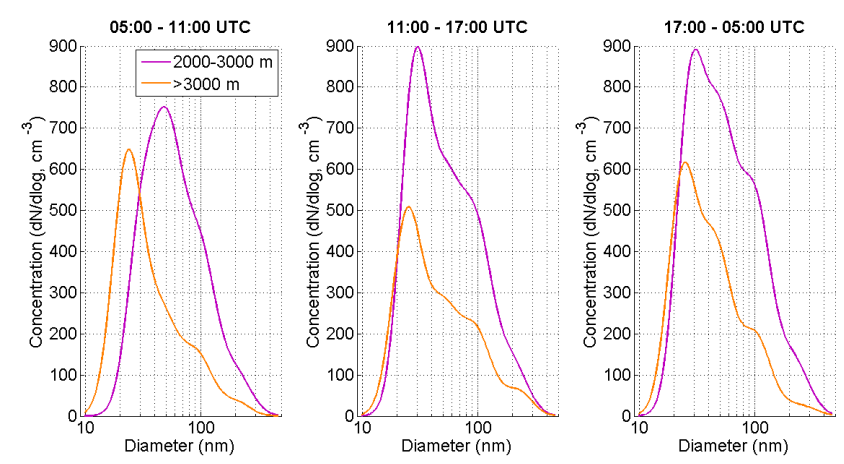

Figure 10. Averaged fitted SMPS size distributions as a function of daytime and altitude.

cut $(20 \mathrm{~nm})$. These reconstructed size distributions do represent the real size distributions measured below $20 \mathrm{~nm}$.

During the time period 11:00-17:00 UTC, the size distributions are dominated by the nucleation mode. In fact, this mode includes $42 \%$ of the particles measured by the SMPS between 2000 and $3000 \mathrm{~m}$, and $48 \%$ above $3000 \mathrm{~m}$. However, both the concentration and the diameter of the nucleation mode appear to be larger between 2000 and $3000 \mathrm{~m}$ compared to higher altitudes (Table A1). Since $N_{5-10}$ concentrations were shown to be comparable for the two altitude ranges (Fig. 7), a faster growth at lower altitudes supported by a larger pool of condensable species could explain the differences observed in the size distributions.

At night (17:00-05:00 UTC), the contributions of nucleation and Aitken modes to the total particle concentration are very similar between 2000 and $3000 \mathrm{~m}$, being around $34 \%$ each, whereas above $3000 \mathrm{~m}$ the nucleation mode is dominant ( $46 \%$ against $36 \%$ for the Aitken mode). These observations suggest that between 2000 and $3000 \mathrm{~m}$, nucleated particles are growing during the course of the day, leaving the nucleation mode, which thus includes a decreasing fraction of the total particle concentration, to reach the Aitken mode. In contrast, it is likely that particle growth is not as fast above $3000 \mathrm{~m}$, since the nucleation mode displays particle concentrations which remain on average higher compared to the Aitken mode, even in the evening. Again, this observation suggests that particle growth could get slower with increasing altitudes.

In the morning (05:00-11:00 UTC), the average size distribution above $3000 \mathrm{~m}$ displays a nucleation mode whose diameter is similar to the diameter observed at night $(\sim 23 \mathrm{~nm})$, and with a contribution to the total particle concentration which is significantly higher than the contribution of the Aitken mode (62 and $21 \%$, respectively). In contrast, between 2000 and $3000 \mathrm{~m}$, the nucleation mode displays a large diameter $(30.5 \mathrm{~nm})$ and a contribution which is lower than the contribution of the Aitken mode (30 and $51 \%$, respectively). We may hypothesize that the small particles which are seen in the nucleation mode above $3000 \mathrm{~m}$ do not originate from 
nucleation events initiated in the morning but were rather formed the day before and are still undergoing a very slow growth process. The low concentration of nucleation-mode particles between 2000 and $3000 \mathrm{~m}$ might be explained by a faster growth for the particles formed the day before, which have thus reached larger diameters, and also by the fact that particles nucleated in the morning (the nucleation probability between 2000 and $3000 \mathrm{~m}$ during the time period 05:0011:00 UTC is $23 \%$ ) may not have already reached the lower detection limit of the SMPS.

\subsubsection{Origin of night-time nanoparticles}

As previously mentioned, nanoparticles in the size range 5$10 \mathrm{~nm}$ were detected during night-time (17:00-05:00 UTC). The purpose of this last section is to investigate their origin, and more particularly to examine the possibility for the nighttime particles to originate from nucleation events triggered earlier during daytime.

The time interval 09:00-12:00 UTC, during which the formation of cluster particles is most frequently observed (Rose et al., 2015a, b), was considered as a reference nucleation period, and only the significant $130 \mathrm{~s}$ averaged $N_{5-10}$ concentrations obtained between 09:00 and 12:00 UTC were further considered. We estimated the half-lifetime of these particles, i.e. the time $t_{\text {fin }}$ at which these concentrations reached half of their initial values, obtained at $t_{0}$, under the following assumptions: (1) particles are removed from the size range $5-10 \mathrm{~nm}$ by coagulation and growth processes and (2) the coagulation sink calculated at $t_{0}$ is constant during particle growth. $t_{\text {fin }}$ is finally given by Eq. (2):

$t_{\text {fin }}=t_{0}+\frac{0.5}{\mathrm{Coag}+\frac{f}{5} \cdot \mathrm{GR}}$,

where Coag is the coagulation sink of $5 \mathrm{~nm}$ particles derived from SMPS data, and GR is the particle growth rate. The factor $f$ represents the fraction of the aerosol population which is activated for growth, and was assumed to be equal to unity.

Particle GRs were estimated from the shift of the nucleation-mode diameter observed on the average SMPS size distributions between night-time (17:00-05:00 UTC) and morning hours (05:00-11:00 UTC) for the altitude range 2000-3000 m (Table A1, Fig. 10). An average value of $0.31 \mathrm{~nm} \mathrm{~h}^{-1}$ was found. However, GR was previously reported to increase with particle size (Yli-Juuti et al., 2011; Kulmala et al., 2013); this is the reason why a lower GR of $0.1 \mathrm{~nm} \mathrm{~h}^{-1}$ was also used to describe particle growth in the size range $5-10 \mathrm{~nm}$. In order to complete our sensitivity study regarding the GR, additional higher value of $1 \mathrm{~nm} \mathrm{~h}^{-1}$ was selected. The results of this analysis are reported in Fig. 11, which indicates that particle lifetime increases with altitude. Such an observation might be explained by decreasing total particle concentrations with increasing altitude, thus leading to lower coagulation sinks. Considering the scenario with an intermediate GR of $0.3 \mathrm{~nm} \mathrm{~h}^{-1}$, initial $N_{5-10}$ con-
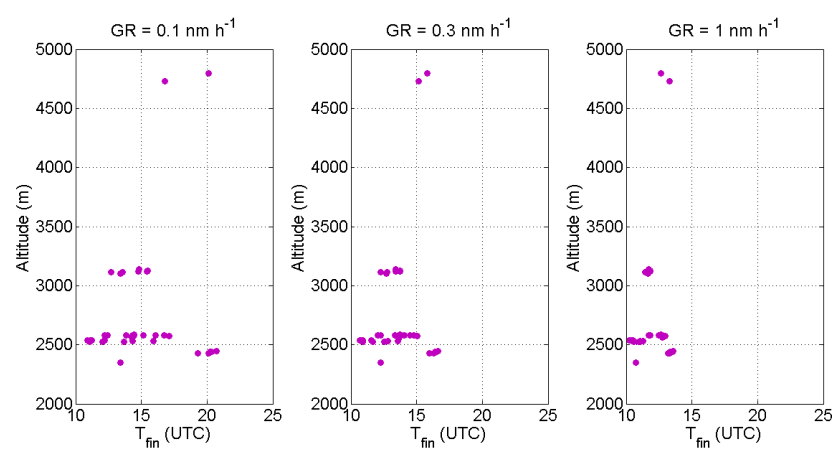

Figure 11. Estimations of $t_{\text {fin }}$, the time at which $N_{5-10}$ concentrations reach half of their initial values, as a function of altitude and particle growth rate.

centrations are all divided by 2 before night-time, suggesting that, considering the relatively high concentrations found at night, there would be an additional source of 5-10 nm particles above $2000 \mathrm{~m}$. The same conclusion is obtained with $\mathrm{GR}=1 \mathrm{~nm} \mathrm{~h}^{-1}$. In contrast, using the more probable value of $\mathrm{GR}=0.1 \mathrm{~nm} \mathrm{~h}^{-1}$, we observe that, for some cases, nanoparticle concentration reaches half of its initial value only after 17:00 UTC, or even later. Because of the reduced number of data points, these conclusions must be considered with caution, but it is likely that a large fraction of nanoparticles detected during the night could be formed earlier during the day. The subsistence of the nanoparticles in the size range 5$10 \mathrm{~nm}$ might be explained by low coagulation sinks coupled with slow particle growth.

\section{Conclusion}

We investigated the occurrence of nucleation events above the Mediterranean Sea using data obtained during research flights performed in the framework of the HYMEX project between September and November 2012.

Based on our observations, nucleation takes place over large areas above the Mediterranean Sea in all air mass types. Nucleation probability slightly varies with air mass origin, but the signature of the different air mass types is, however, complex to distinguish in terms of $N_{5-10}$ concentrations. In western Europe and southern Mediterranean Sea flows, more frequently observed compared to other air mass types, maximum concentrations were obtained for fetches around $5 \mathrm{~h}$, but significant concentrations persist over fetches up to $60 \mathrm{~h}$, suggesting that the nucleation process could be more influenced by parameters inherent to the marine troposphere.

The analysis of the vertical extension of nucleation showed that the process could be promoted above $1000 \mathrm{~m}$, and especially between 2000 and $3000 \mathrm{~m}$. Simultaneous analysis of the boundary layer height indicated that these altitudes often corresponded to free-tropospheric conditions. Vertical gradient of the condensation sink, together with temperature and 
humidity, might explain the increasing nucleation probability with altitude. The mixing of two air parcels with contrasting properties (temperature, $\mathrm{RH}$, condensation sink, precursors) could also support the occurrence of nucleation at preferential altitudes. In addition, for a given altitude range, larger $N_{5-10}$ concentrations were often co-located with increased CS, likely associated with higher oxidation of gasphase precursors. This last observation suggests inputs from the $\mathrm{BL}$ that might be the result of convective movements of air parcels induced by clouds and their outflow. The fact that clusters might also be transported from lower altitudes through such processes cannot be excluded.

The investigation of the global shape of the particle size distributions derived from SMPS measurements finally allowed us to study the particle growth above $2000 \mathrm{~m}$, and more particularly the relative contribution of the different particle modes to the total concentration as a function of time and altitude. After they formed, particles appear to grow to larger sizes above $2000 \mathrm{~m}$, reaching the Aitken-mode range, but with growth rates which seem to decrease with altitude. This slow growth, coupled with low coagulation sinks, may favour longer subsistence for nanoparticles in the size range 5-10 nm, and could explain the detection of these small particles during night-time, several hours after their formation.

Our findings demonstrate that higher altitudes could promote the occurrence of NPF, not only over continental areas, as previously suggested by Boulon et al. (2011), but also over open seas, with indications of marine precursors. This result supports the model study by Makkonen et al. (2012), which predicts that nucleation could have a significant contribution to the cloud condensation nuclei $(\mathrm{CCN})$ concentration over the Mediterranean Sea, and indicates that this contribution could be even more decisive at higher altitudes, where clouds form. 


\section{Appendix A}

Table A1. Parameters of the Gaussians used to fit the SMPS size distributions as a function of daytime for the altitude ranges above $2000 \mathrm{~m}$.

\begin{tabular}{|c|c|c|c|}
\hline \multicolumn{4}{|c|}{ (a) 05:00-11:00 } \\
\hline Mode & Parameters & $2000-3000 \mathrm{~m}$ & $>3000 \mathrm{~m}$ \\
\hline \multirow[t]{3}{*}{ M1 } & $N\left(\mathrm{~cm}^{-3}\right)$ & $126.3 \pm 70.4$ & $203.5 \pm 116.5$ \\
\hline & $\sigma$ & $1.32 \pm 0.01$ & $1.35 \pm 0.03$ \\
\hline & $d_{p}(\mathrm{~nm})$ & $30.5 \pm 3.0$ & $23.1 \pm 3.5$ \\
\hline \multirow[t]{3}{*}{ M2 } & $N\left(\mathrm{~cm}^{-3}\right)$ & $211.3 \pm 130.1$ & $70.6 \pm 51.7$ \\
\hline & $\sigma$ & $1.36 \pm 0.02$ & $1.37 \pm 0.01$ \\
\hline & $d_{p}(\mathrm{~nm})$ & $51.6 \pm 5.1$ & $46.7 \pm 7.5$ \\
\hline \multirow[t]{3}{*}{ M3 } & $N\left(\mathrm{~cm}^{-3}\right)$ & $130.4 \pm 88.0$ & $45.8 \pm 22.6$ \\
\hline & $\sigma$ & $1.37 \pm 0$ & $1.37 \pm 0.01$ \\
\hline & $d_{p}(\mathrm{~nm})$ & $99.7 \pm 9.5$ & $94.9 \pm 8.7$ \\
\hline \multirow[t]{3}{*}{ M4 } & $N\left(\mathrm{~cm}^{-3}\right)$ & $30.9 \pm 26.9$ & $9.4 \pm 9.5$ \\
\hline & $\sigma$ & $1.35 \pm 0.05$ & $1.31 \pm 0.03$ \\
\hline & $d_{p}(\mathrm{~nm})$ & $205.4 \pm 13.7$ & $207.1 \pm 8.5$ \\
\hline \multicolumn{4}{|c|}{ (b) $11: 00-17: 00$} \\
\hline Mode & Parameters & $2000-3000 \mathrm{~m}$ & $>3000 \mathrm{~m}$ \\
\hline \multirow[t]{3}{*}{ M1 } & $N\left(\mathrm{~cm}^{-3}\right)$ & $248.1 \pm 130.0$ & $155.1 \pm 126.0$ \\
\hline & $\sigma$ & $1.32 \pm 0.02$ & $1.34 \pm 0.03$ \\
\hline & $d_{p}(\mathrm{~nm})$ & $28.6 \pm 3.6$ & $24.6 \pm 4.8$ \\
\hline \multirow[t]{3}{*}{ M2 } & $N\left(\mathrm{~cm}^{-3}\right)$ & $161.8 \pm 174.4$ & $83.5 \pm 46.9$ \\
\hline & $\sigma$ & $1.36 \pm 0.02$ & $1.37 \pm 0.01$ \\
\hline & $d_{p}(\mathrm{~nm})$ & $52.4 \pm 5.8$ & $49.7 \pm 7.4$ \\
\hline \multirow[t]{3}{*}{ M3 } & $N\left(\mathrm{~cm}^{-3}\right)$ & $150.8 \pm 124.7$ & $67.4 \pm 36.0$ \\
\hline & $\sigma$ & $1.38 \pm 0.01$ & $1.37 \pm 0.01$ \\
\hline & $d_{p}(\mathrm{~nm})$ & $99.7 \pm 8.9$ & $97.5 \pm 10.0$ \\
\hline \multirow[t]{3}{*}{ M4 } & $N\left(\mathrm{~cm}^{-3}\right)$ & $39.0 \pm 38.6$ & $17.7 \pm 19.4$ \\
\hline & $\sigma$ & $1.35 \pm 0.04$ & $1.32 \pm 0.04$ \\
\hline & $d_{p}(\mathrm{~nm})$ & $201.9 \pm 12.7$ & $224.3 \pm 48.4$ \\
\hline \multicolumn{4}{|c|}{ (c) $17: 00-05: 00$} \\
\hline Mode & Parameters & $2000-3000 \mathrm{~m}$ & $>3000 \mathrm{~m}$ \\
\hline \multirow[t]{3}{*}{ M1 } & $N\left(\mathrm{~cm}^{-3}\right)$ & $224.9 \pm 156.7$ & $176.6 \pm 117.7$ \\
\hline & $\sigma$ & $1.32 \pm 0.02$ & $1.33 \pm 0.03$ \\
\hline & $d_{p}(\mathrm{~nm})$ & $27.7 \pm 3.1$ & $23.8 \pm 3.5$ \\
\hline \multirow[t]{3}{*}{ M2 } & $N\left(\mathrm{~cm}^{-3}\right)$ & $227.2 \pm 169.4$ & $136.9 \pm 9.9$ \\
\hline & $\sigma$ & $1.37 \pm 0$ & $1.37 \pm 0$ \\
\hline & $d_{p}(\mathrm{~nm})$ & $50.6 \pm 4.1$ & $46.4 \pm 5.6$ \\
\hline \multirow[t]{3}{*}{ M3 } & $N\left(\mathrm{~cm}^{-3}\right)$ & $167.3 \pm 108.7$ & $61.4 \pm 58.4$ \\
\hline & $\sigma$ & $1.36 \pm 0.01$ & $1.35 \pm 0.02$ \\
\hline & $d_{p}(\mathrm{~nm})$ & $101.6 \pm 7.7$ & $102.8 \pm 8.4$ \\
\hline \multirow[t]{3}{*}{ M4 } & $N\left(\mathrm{~cm}^{-3}\right)$ & $44.7 \pm 40.7$ & $9.2 \pm 6.2$ \\
\hline & $\sigma$ & $1.37 \pm 0.05$ & $1.39 \pm 0.04$ \\
\hline & $d_{p}(\mathrm{~nm})$ & $216.4 \pm 17.9$ & $240.3 \pm 12.1$ \\
\hline
\end{tabular}




\section{Appendix B}
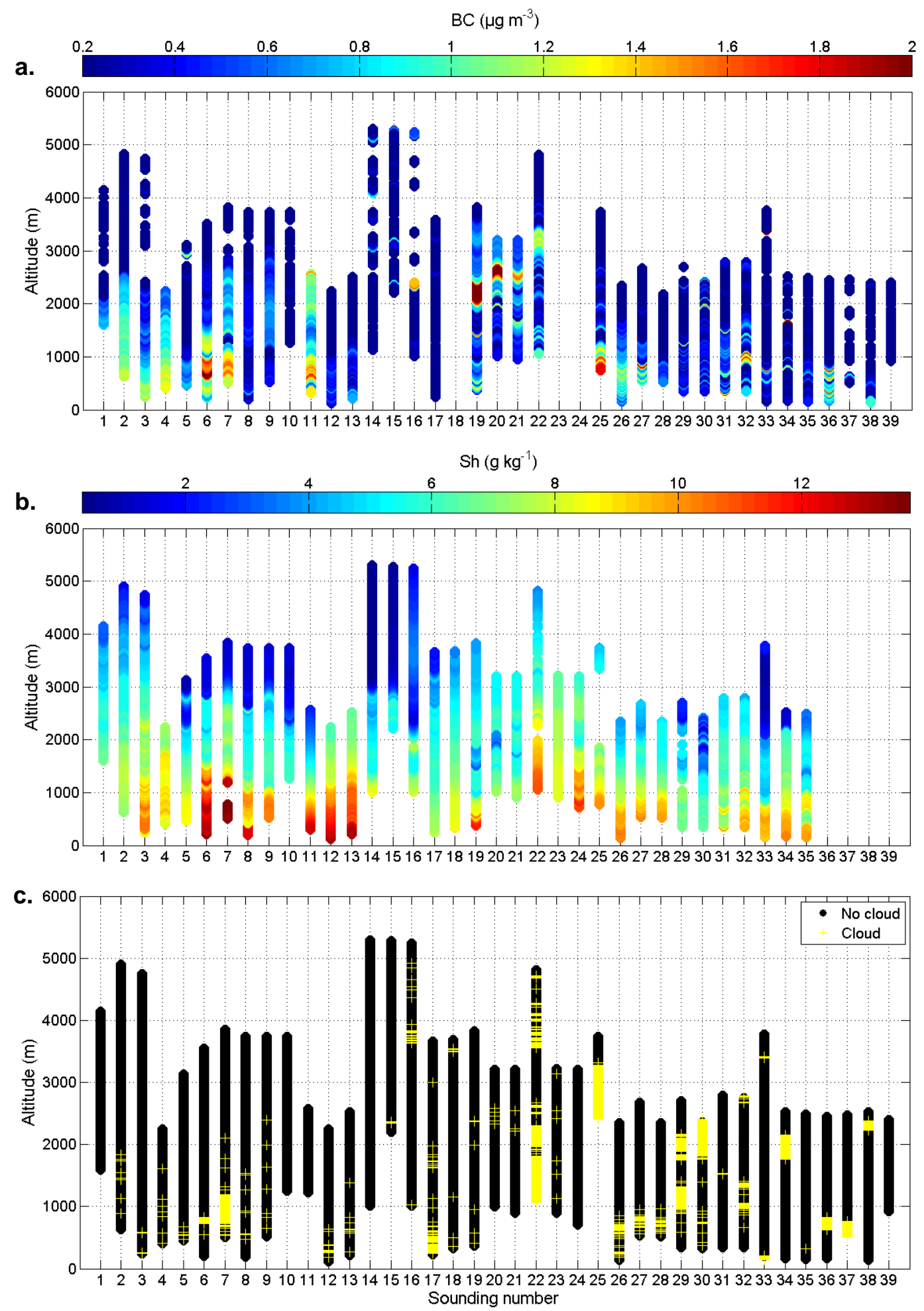

Figure B1. Profiles of (a) BC, (b) specific humidity and (c) cloud cover during the ATR-42 soundings performed above the sea. 
Acknowledgements. HyMeX SOP1 was supported by CNRS, Météo-France, CNES, IRSTEA and INRA through the large interdisciplinary international programme MISTRALS (Mediterranean Integrated STudies at Regional And Local Scales), dedicated to the understanding of the Mediterranean Basin environmental processes (http://www.mistrals-home.org). We also would like to thank SAFIRE for their support during instrument integration on the French ATR-42 and HYMEX SOP1 campaign execution. We finally gratefully acknowledge the NOAA Air Resource Laboratory (ARL) for the provision of the HYSPLIT READY website (http://www.arl.noaa.gov/ready.php) used in this publication for calculating the trajectories.

Edited by: F. Khosrawi

\section{References}

Asmi, E., Frey, A., Virkkula, A., Ehn, M., Manninen, H. E., Timonen, H., Tolonen-Kivimäki, O., Aurela, M., Hillamo, R., and Kulmala, M.: Hygroscopicity and chemical composition of Antarctic sub-micrometre aerosol particles and observations of new particle formation, Atmos. Chem. Phys., 10, 4253-4271, doi:10.5194/acp-10-4253-2010, 2010.

Birmili, W., Berresheim, H., Plass-Dülmer, C., Elste, T., Gilge, S., Wiedensohler, A., and Uhrner, U.: The Hohenpeissenberg aerosol formation experiment (HAFEX): a long-term study including size-resolved aerosol, $\mathrm{H}_{2} \mathrm{SO}_{4}, \mathrm{OH}$, and monoterpenes measurements, Atmos. Chem. Phys., 3, 361-376, doi:10.5194/acp-3-361-2003, 2003.

Bond, T. C., Anderson, T. L., and Campbell, D.: Calibration and intercomparison of filter-based measurements of visible light absorption by aerosols, Aerosol Sci. Technol., 30, 582-600, 1999.

Boulon, J., Sellegri, K., Venzac, H., Picard, D., Weingartner, E., Wehrle, G., Collaud Coen, M., Bütikofer, R., Flückiger, E., Baltensperger, U., and Laj, P.: New particle formation and ultrafine charged aerosol climatology at a high altitude site in the Alps (Jungfraujoch, $3580 \mathrm{~m}$ a.s.l., Switzerland), Atmos. Chem. Phys., 10, 9333-9349, doi:10.5194/acp-10-9333-2010, 2010.

Boulon, J., Sellegri, K., Hervo, M., Picard, D., Pichon, J.-M., Fréville, P., and Laj, P.: Investigation of nucleation events vertical extent: a long term study at two different altitude sites, Atmos. Chem. Phys., 11, 5625-5639, doi:10.5194/acp-11-56252011, 2011.

Boy, M., Petäjä, T., Dal Maso, M., Rannik, Ü., Rinne, J., Aalto, P., Laaksonen, A., Vaattovaara, P., Joutsensaari, J., Hoffmann, T., Warnke, J., Apostolaki, M., Stephanou, E. G., Tsapakis, M., Kouvarakis, A., Pio, C., Carvalho, A., Römpp, A., Moortgat, G., Spirig, C., Guenther, A., Greenberg, J., Ciccioli, P., and Kulmala, M.: Overview of the field measurement campaign in Hyytiälä, August 2001 in the framework of the EU project OSOA, Atmos. Chem. Phys., 4, 657-678, doi:10.5194/acp-4-657-2004, 2004.

Brock, C. A., Trainer, M., Ryerson, T. B., Neuman, J. A., Parrish, D. D., Holloway, J. S., Nicks, D. K., Frost, G. J., Hübler, G., Fehsenfeld, F. C., Wilson, J. C., Reeves, J. M., Lafleur, B. G., Hilbert, H., Atlas, E. L., Donnelly, S. G., Schauffler, S. M., Stroud, V. R. and Wiedinmyer, C.: Particle growth in urban and industrial plumes in Texas, J. Geophys. Res., 108, 4111, doi:10.1029/2002JD002746, 2003.
Clarke, A. D., Varner, J. L., Eisele, F., Mauldin, R. L., Tanner, D., and Litchy, M.: Particle production in the remote marine atmosphere: Cloud outflow and subsidence during ACE 1, J. Geophys. Res.-Atmos., 103, 16397-16409, doi:10.1029/97JD02987, 1998.

Crumeyrolle, S., Manninen, H. E., Sellegri, K., Roberts, G., Gomes, L., Kulmala, M., Weigel, R., Laj, P., and Schwarzenboeck, A.: New particle formation events measured on board the ATR-42 aircraft during the EUCAARI campaign, Atmos. Chem. Phys., 10, 6721-6735, doi:10.5194/acp-10-6721-2010, 2010.

Dall'Osto, M., Querol, X., Alastuey, A., O'Dowd, C., Harrison, R. M., Wenger, J., and Gómez-Moreno, F. J.: On the spatial distribution and evolution of ultrafine particles in Barcelona, Atmos. Chem. Phys., 13, 741-759, doi:10.5194/acp-13-741-2013, 2013.

Dal Maso, M., Kulmala, M., Riipinen, I., Wagner, R., Hussein, T., Aalto, P. P., and Lehtinen, K. E.: Formation and growth of fresh atmospheric aerosols: eight years of aerosol size distribution data from SMEAR II, Hyytiala, Finland, Boreal Environ. Res., 10, 323-336, 2005.

Draxler, R. R. and Rolph, G. D.: HYSPLIT (Hybrid Single-Particle Langrangian Integrated Trajectory) Model access via NOAA ARL READY website, available at: http://www.arl.noaa.gov/ ready/hysplit4.html (last access: 15 September 2014), 2003.

Drewnick, F., Hings, S. S., DeCarlo, P., Jayne, J. T., Gonin, M., Fuhrer, K., Weimer, S., Jimenez, J. L., Demerjian, K. L., Borrmann, S., and Worsnop, D. R.: A New Time-of-Flight Aerosol Mass Spectrometer (TOF-AMS) - Instrument Description and First Field Deployment, Aerosol Sci. Technol., 39, 637-658, doi:10.1080/02786820500182040, 2005.

Heintzenberg, J., Covert, D. C., and Van Dingenen, R.: Size distribution and chemical composition of marine aerosols: a compilation and review, Tellus B, 52, 1104-1122, 2000.

Venzac, H., Sellegri, K., Laj, P., Villani, P., Bonasoni, P., Marinoni, A., Cristofanelli, P., Calzolari, F., Fuzzi, S., Decesari, S., Facchini, M.-C., Vuillermoz, E., and Pietro Verza, G.: High Frequency New Particle Formation in the Himalayas, P. Natl. Acad. Sci., 105, 15666-15671, 2008.

Jeong, C.-H., Hopke, P. K., Chalupa, D., and Utell, M.: Characteristics of Nucleation and Growth Events of Ultrafine Particles Measured in Rochester, NY, Environ. Sci. Technol., 38, 1933-1940, doi:10.1021/es034811p, 2004.

Junkermann, W.: An Ultralight Aircraft as Platform for Research in the Lower Troposphere: System Performance and First Results from Radiation Transfer Studies in Stratiform Aerosol Layers and Broken Cloud Conditions, J. Atmos. Ocean. Technol., 18, 934-946, doi:10.1175/15200426(2001)018<0934:AUAAPF>2.0.CO;2, 2001.

Junkermann, W.: The actinic UV-radiation budget during the ESCOMPTE campaign 2001: results of airborne measurements with the microlight research aircraft D-MIFU, Atmos. Res., 74, 461-475, doi:10.1016/j.atmosres.2004.06.009, 2005.

Kerminen, V.-M., Paramonov, M., Anttila, T., Riipinen, I., Fountoukis, C., Korhonen, H., Asmi, E., Laakso, L., Lihavainen, H., Swietlicki, E., Svenningsson, B., Asmi, A., Pandis, S. N., Kulmala, M., and Petäjä, T.: Cloud condensation nuclei production associated with atmospheric nucleation: a synthesis based on existing literature and new results, Atmos. Chem. Phys., 12, 1203712059, doi:10.5194/acp-12-12037-2012, 2012. 
Khosrawi, F. and Konopka, P.: Enhanced particle formation and growth due to mixing processes in the tropopause region, Atmos. Environ., 37, 903-910, 2003.

Khosrawi, F., Ström, J., Minikin, A., and Krejci, R.: Particle formation in the Arctic free troposphere during the ASTAR 2004 campaign: a case study on the influence of vertical motion on the binary homogeneous nucleation of $\mathrm{H}_{2} \mathrm{SO}_{4} / \mathrm{H}_{2} \mathrm{O}$, Atmos. Chem. Phys., 10, 1105-1120, doi:10.5194/acp-10-1105-2010, 2010.

Koren, I., Dagan, G., and Altaratz, O.: From aerosol-limited to invigoration of warm convective clouds, Science, 344, 1143-1146, doi:10.1126/science.1252595, 2014.

Kristensson, A., Johansson, M., Swietlicki, E., Kivekäs, N., Hussein, T., Nieminen, T., Kulmala, M., and Dal Maso, M.: NanoMap: Geographical mapping of atmospheric new particle formation through analysis of particle number size distribution and trajectory data, Boreal Environ. Res., 19, 329-342, 2014.

Kulmala, M. and Kerminen, V.-M.: On the formation and growth of atmospheric nanoparticles, Atmos. Res., 90, 132-150, doi:10.1016/j.atmosres.2008.01.005, 2008.

Kulmala, M., Vehkamäki, H., Petäjä, T., Dal Maso, M., Lauri, A., Kerminen, V.-M., Birmili, W., and McMurry, P. H.: Formation and growth rates of ultrafine atmospheric particles: a review of observations, J. Aerosol Sci., 35, 143-176, 2004.

Kulmala, M., Kontkanen, J., Junninen, H., Lehtipalo, K., Manninen, H. E., Nieminen, T., Petäjä, T., Sipilä, M., Schobesberger, S., Rantala, P., Franchin, A., Jokinen, T., Järvinen, E., Äijälä, M., Kangasluoma, J., Hakala, J., Aalto, P. P., Paasonen, P., Mikkilä, J., Vanhanen, J., Aalto, J., Hakola, H., Makkonen, U., Ruuskanen, T., Mauldin, R. L., Duplissy, J., Vehkamäki, H., Bäck, J., Kortelainen, A., Riipinen, I., Kurtén, T., Johnston, M. V., Smith, J. N., Ehn, M., Mentel, T. F., Lehtinen, K. E. J., Laaksonen, A., Kerminen, V.-M., and Worsnop, D. R.: Direct Observations of Atmospheric Aerosol Nucleation, Science, 339, 943946, doi:10.1126/science.1227385, 2013.

Laakso, L., Grönholm, T., Kulmala, L., Haapanala, S., Hirsikko, A., Lovejoy, E. R., Kazil, J., Kurten, T., Boy, M., Nilsson, E. D., Sogachev, A., Riipinen, I., Stratmann, F., and Kulmala, M.: Hot-air balloon as a platform for boundary layer profile measurements during particle formation, Boreal Environ. Res., 12, 279-294, 2007

Lee, S.-H., Young, L.-H., Benson, D. R., Suni, T., Kulmala, M., Junninen, H., Campos, T. L., Rogers, D. C., and Jensen, J.: Observations of nighttime new particle formation in the troposphere, J. Geophys. Res.-Atmos., 113, D10210, doi:10.1029/2007JD009351, 2008.

Makkonen, R., Asmi, A., Kerminen, V.-M., Boy, M., Arneth, A., Hari, P., and Kulmala, M.: Air pollution control and decreasing new particle formation lead to strong climate warming, Atmos. Chem. Phys., 12, 1515-1524, doi:10.5194/acp-12-15152012, 2012.

Manninen, H. E., Nieminen, T., Asmi, E., Gagné, S., Häkkinen, S., Lehtipalo, K., Aalto, P., Vana, M., Mirme, A., Mirme, S., Hõrrak, U., Plass-Dülmer, C., Stange, G., Kiss, G., Hoffer, A., Töro, N., Moerman, M., Henzing, B., de Leeuw, G., Brinkenberg, M., Kouvarakis, G. N., Bougiatioti, A., Mihalopoulos, N., O’Dowd, C., Ceburnis, D., Arneth, A., Svenningsson, B., Swietlicki, E., Tarozzi, L., Decesari, S., Facchini, M. C., Birmili, W., Sonntag, A., Wiedensohler, A., Boulon, J., Sellegri, K., Laj, P., Gysel, M., Bukowiecki, N., Weingartner, E., Wehrle, G., Laakso- nen, A., Hamed, A., Joutsensaari, J., Petäjä, T., Kerminen, V.-M., and Kulmala, M.: EUCAARI ion spectrometer measurements at 12 European sites - analysis of new particle formation events, Atmos. Chem. Phys., 10, 7907-7927, doi:10.5194/acp-10-79072010, 2010.

Mirme, S., Mirme, A., Minikin, A., Petzold, A., Hõrrak, U., Kerminen, V.-M., and Kulmala, M.: Atmospheric sub-3 nm particles at high altitudes, Atmos. Chem. Phys., 10, 437-451, doi:10.5194/acp-10-437-2010, 2010.

Nilsson, E. D. and Kulmala, M.: The potential for atmospheric mixing processes to enhance the binary nucleation rate, J. Geophys. Res.-Atmos., 103, 1381-1389, 1998.

O'Dowd, C. D. and de Leeuw, G.: Marine aerosol production: a review of the current knowledge, Philos. T. R. Soc. A, 365, $1753-$ 1774, doi:10.1098/rsta.2007.2043, 2007.

O'Dowd, C. D., Geever, M., Hill, M. K., Smith, M. H., and Jennings, S. G.: New particle formation: Nucleation rates and spatial scales in the clean marine coastal environment, Geophys. Res. Lett., 25, 1661-1664, 1998.

O’Dowd, C. D., Hämeri, K., Mäkelä, J., Väkeva, M., Aalto, P., de Leeuw, G., Kunz, G. J., Becker, E., Hansson, H.-C., Allen, A. G., Harrison, R. M., Berresheim, H., Kleefeld, C., Geever, M., Jennings, S. G., and Kulmala, M.: Coastal new particle formation: Environmental conditions and aerosol physicochemical characteristics during nucleation bursts, J. Geophys. Res.-Atmos., 107, PAR12.1-PAR12.17, doi:10.1029/2000JD000206, 2002.

O’Dowd, C. D., Yoon, Y. J., Junkermann, W., Aalto, P., Kulmala, M., Lihavainen, H., and Viisanen, Y.: Airborne measurements of nucleation mode particles II: boreal forest nucleation events, Atmos. Chem. Phys., 9, 937-944, doi:10.5194/acp-9-937-2009, 2009.

Pirjola, L., O'Dowd, C. D., Brooks, I. M., and Kulmala, M.: Can new particle formation occur in the clean marine boundary layer?, J. Geophys. Res., 105, 26531-26546, doi:10.1029/2000JD900310, 2000.

Rose, C., Sellegri, K., Asmi, E., Hervo, M., Freney, E., Colomb, A., Junninen, H., Duplissy, J., Sipilä, M., Kontkanen, J., Lehtipalo, K., and Kulmala, M.: Major contribution of neutral clusters to new particle formation at the interface between the boundary layer and the free troposphere, Atmos. Chem. Phys., 15, 34133428, doi:10.5194/acp-15-3413-2015, 2015a.

Rose, C., Sellegri, K., Velarde, F., Moreno, I., Ramonet, M., Weinhold, K., Krejci, R., Andrade, M., Wiedensohler, A., and Laj, P.: Frequent nucleation events at the high altitude station of Chacaltaya (5240 m a.s.1.), Bolivia, Atmos. Environ., 102, 18-29, doi:10.1016/j.atmosenv.2014.11.015, 2015b.

Rosenfeld, D., Sherwood, S., Wood, R., and Donner, L.: Climate Effects of Aerosol-Cloud Interactions, Science, 343, 379-380, doi:10.1126/science.1247490, 2014.

Schobesberger, S., Väänänen, R., Leino, K., Virkkula, A., Backman, J., Pohja, T., Siivola, E., Franchin, A., Mikkilä, J., Paramonov, M., Aalto, P. P., Krejci, R., Petäjä, T., and Kulmala, M.: Airborne measurements over the boreal forest of southern Finland during new particle formation events in 2009 and 2010, Boreal Environ. Res., 18, 145-163, 2013.

Seidel, D. J., Ao, C. O., and Li, K.: Estimating climatological planetary boundary layer heights from radiosonde observations: Comparison of methods and uncertainty analysis, J. Geophys. Res.Atmos., 115, D16113, doi:10.1029/2009JD013680, 2010. 
Sellegri, K., Yoon, Y. J., Jennings, S. G., O’Dowd, C. D., Pirjola, L., Cautenet, S., Chen, H., and Hoffmann, T.: Quantification of Coastal New Ultra-Fine Particles Formation from In situ and Chamber Measurements during the BIOFLUX Campaign, Environ. Chem., 2, 260-270, 2005.

Sihto, S.-L., Kulmala, M., Kerminen, V.-M., Dal Maso, M., Petäjä, T., Riipinen, I., Korhonen, H., Arnold, F., Janson, R., Boy, M., Laaksonen, A., and Lehtinen, K. E. J.: Atmospheric sulphuric acid and aerosol formation: implications from atmospheric measurements for nucleation and early growth mechanisms, Atmos. Chem. Phys., 6, 4079-4091, doi:10.5194/acp-6-4079-2006, 2006.

Suni, T., Kulmala, M., Hirsikko, A., Bergman, T., Laakso, L., Aalto, P. P., Leuning, R., Cleugh, H., Zegelin, S., Hughes, D., van Gorsel, E., Kitchen, M., Vana, M., Hõrrak, U., Mirme, S., Mirme, A., Sevanto, S., Twining, J., and Tadros, C.: Formation and characteristics of ions and charged aerosol particles in a native Australian Eucalypt forest, Atmos. Chem. Phys., 8, 129-139, doi:10.5194/acp-8-129-2008, 2008.

Tao, W.-K., Chen, J.-P., Li, Z., Wang, C., and Zhang, C.: Impact of aerosols on convective clouds and precipitation, Rev. Geophys., 50, RG2001, doi:10.1029/2011RG000369, 2012.

Tunved, P., Nilsson, E. D., Hansson, H.-C., Ström, J., Kulmala, M., Aalto, P., and Viisanen, Y.: Aerosol characteristics of air masses in northern Europe: Influences of location, transport, sinks, and sources, J. Geophys. Res.-Atmos., 110, D07201, doi:10.1029/2004JD005085, 2005.

Vaattovaara, P., Huttunen, P. E., Yoon, Y. J., Joutsensaari, J., Lehtinen, K. E. J., O'Dowd, C. D., and Laaksonen, A.: The composition of nucleation and Aitken modes particles during coastal nucleation events: evidence for marine secondary organic contribution, Atmos. Chem. Phys., 6, 4601-4616, doi:10.5194/acp-64601-2006, 2006.
Weber, R. J., Clarke, A. D., Litchy, M., Li, J., Kok, G., Schillawski, R. D., and McMurry, P. H.: Spurious aerosol measurements when sampling from aircraft in the vicinity of clouds, J. Geophys. Res., 103, 28337, doi:10.1029/98JD02086, 1998.

Weigel, R., Hermann, M., Curtius, J., Voigt, C., Walter, S., Böttger, T., Lepukhov, B., Belyaev, G., and Borrmann, S.: Experimental characterization of the COndensation PArticle counting System for high altitude aircraft-borne application, Atmos. Meas. Tech., 2, 243-258, doi:10.5194/amt-2-243-2009, 2009.

Wiedensohler, A., Cheng, Y. F., Nowak, A., Wehner, B., Achtert, P., Berghof, M., Birmili, W., Wu, Z. J., Hu, M., and Zhu, T.: Rapid aerosol particle growth and increase of cloud condensation nucleus activity by secondary aerosol formation and condensation: A case study for regional air pollution in northeastern China, J. Geophys. Res.-Atmos., 114, D00G08, doi:10.1029/2008JD010884, 2009.

Yli-Juuti, T., Nieminen, T., Hirsikko, A., Aalto, P. P., Asmi, E., Hõrrak, U., Manninen, H. E., Patokoski, J., Dal Maso, M., Petäjä, T., Rinne, J., Kulmala, M., and Riipinen, I.: Growth rates of nucleation mode particles in Hyytiälä during 20032009: variation with particle size, season, data analysis method and ambient conditions, Atmos. Chem. Phys., 11, 12865-12886, doi:10.5194/acp-11-12865-2011, 2011.

Young, L.-H., Benson, D. R., Montanaro, W. M., Lee, S.-H., Pan, L. L., Rogers, D. C., Jensen, J., Stith, J. L., Davis, C. A., Campos, T. L., Bowman, K. P., Cooper, W. A., and Lait, L. R.: Enhanced new particle formation observed in the northern midlatitude tropopause region, J. Geophys. Res., 112, D10218, doi:10.1029/2006JD008109, 2007. 